\title{
POT LEACHATES FROM WHEAT AND RYEGRASS HYBRID TYPE AFFECT THE GROWTH AND COMPOSITION OF MICROBIAL COMMUNITIES IN THE SOIL
}

\author{
MI Ferreira ${ }^{1}$, CM Reinhardt ${ }^{2}$, M Van Der Rijst ${ }^{3}$, A Marais ${ }^{1} \&$ A Botha ${ }^{4}$ \\ ${ }^{1}$ Directorate Plant Sciences, Western Cape Department of Agriculture, Private Bag X1, Elsenburg, 7607, South \\ Africa \\ ${ }^{2}$ Department of Plant Production and Soil Science, University of Pretoria, Pretoria, 0002, South Africa. \\ ${ }^{3}$ Agricultural Research Council Biometry Unit, Private Bag X5013, Stellenbosch, 7599, South Africa and \\ ${ }^{4}$ Department of Microbiology, Stellenbosch University, Private Bag X1, Matieland, 7602, South Africa
}

http://doi.org/10.35410/IJAEB.2019.4467

\begin{abstract}
There is growing interest in understanding microbial communities to promote sustainable agricultural production systems. Plant roots produce exudates which serve as important carbon and energy sources for micro-organisms contained in the rhizosphere. The objectives of this study were to compare the effects of leachates from wheat and ryegrass hybrid type (Lolium multiflorum $\mathrm{x}$ L. perenne) on the plant growth rate and simultaneously study the physiological profile of the soil microbial community, determined by using the Biolog EcoPlateTM system. Higher protozoan numbers were observed in the rhizosphere of L. multiflorum $\mathrm{x}$ L. perenne which received leachates from both test species. A microbial community able to readily utilise $\alpha$ ketobutyric acid was observed when L. multiflorum x L. perenne leachate was added to control pots. Therefore, leachate from donor plants had a definite influence on the functional soil microbial community of acceptor plants. Furthermore, the close correlation of protozoan numbers with the utilisation of $\alpha$ keto- butyric acid, suggest that the protozoa actively grazed on this altered microbial community.
\end{abstract}

Keywords: Carbon utilisation, Lolium multiflorum x L. perenne, soil microbial community, root exudates, ryegrass hybrid type leachates, wheat.

\section{INTRODUCTION}

There is growing interest in understanding and manipulating soil microbial communities to promote sustainable agricultural production systems (Xue et al., 2018). According to Bertin et al. (2003) plant roots serve a multitude of functions including anchoring plants, delivering nutrients and water, as well as producing exudates with growth-regulatory properties. The root-soil interface, or rhizosphere, is the site of greatest activity within the soil matrix since all roots have the ability to secrete chemical compounds which increase in response to biotic and abiotic stress factors. These root exudates may comprise a wide variety of metabolites including carbohydrates, proteins, vitamins, amino acids, and other organic compounds (Kong et al., 2008). 
Results by Xue et al. (2018) showed that soils contain highly diverse microbial communities that affect plant growth directly, through pathogenic or beneficial symbioses, and indirectly via fixation and cycling of nutrients. This was confirmed by Sasse et al. (2018) who reported that soil microorganisms have the ability to alter plant development. It is also known that there is a tight relationship between root exudates and microbial diversity (Eisenhauer et al., 2017). Canarini et a.l (2018) reported that the flow of root exudates could represent a key determinate of root growth and development, by affecting temporary concentrations of organic solutes at the root tip.

Root exudation serves as an important carbon and energy source for microorganisms in the rhizosphere (Quian et al., 1997). However, some low molecular weight root exudates may also act as allelochemicals mediating interactions between the plants and other organisms in the rhizosphere (Bertin et al., 2003). Allelopathic processes involve secretion of bioactive compounds from both plants and microorganisms resulting in the inhibition or stimulation of physiological processes in neighbouring individuals belonging to either the same or different species (Kazinczi et al., 2005; Weston, 2005; Gu et al., 2008b). As early as 1991, Meharg \& Killham found that soil microflora may stimulate root exudates.

Due to the fact that soil microbes have functional interactions with their environment, it is important to analyse the microbial communities in the soil as a single ecological unit (Garland et al., 2007). Molecular methods have been used to measure changes in microbial communities (Juhanson et al., 2007; Rahman et al., 2008). However, Ellis et al. (2003) found that the culturable microbe fraction of the soil community often acts as indicator of soil disturbances. According to Xue et al. (2018) the assembly of microbial communities in agroecosystems responds both to factors outside of the control of crop producers, such as soil type and climate, as well as factors under their control, such as crop type and varieties, rotation system, plant nutrition and crop protection practices. Sasse et al (2018) emphasised that environmental factors had a larger impact on microbial diversity than did plant diversity and high plant diversity likely promotes a diverse microbial community.

A number of researchers have analysed the culturable microbial community in soil using the Biolog ${ }^{\text {TM }}$ system (Garland \& Mills, 1991; Pennanen, 2001; Zhang et al., 2009). By using the Biolog EcoPlate ${ }^{\mathrm{TM}}$ system microbes in the soil solution are presented with 31 different carbon sources. The contention is that the resulting carbon assimilation pattern observed on the plates presents the observer with a characteristic physiological profile of the soil microbial community (www.biolog.com). Any changes in the composition of the soil microbial community will thus be reflected in changes in the carbon source utilisation pattern. Zhang et al. (2009) was able to use the methodology to distinguish between sites contaminated by the plant invader Solidago canadensis L. and pristine sites while Grayston et al. (1998) revealed different carbon utilisation patterns associated the microbial communities within the rhizosphere of different plant species.

In South Africa's Western Cape Province, wheat (Triticum aestivum L.) cropping systems are invaded by ryegrass hybrid type (Lolium multiflorum $\mathrm{x}$ L. perenne) identified by the Compton Herbarium, Kirstenbosch Botanical Gardens (Ferreira et al., 2015). Very little is 
known about this hybrid weed type, which is highly invasive and easily develops herbicide resistance, creating weed management problems. Our hypothesis is that one of the weed's invasive mechanisms is to change the soil microbial characteristics, including that of wheat cropping systems where it is most pervasive and thereby altering plant performance. The first objective of this study was to compare the effects of pot leachates from wheat and L. multiflorum $\mathrm{x}$ L. perenne grown in two different soil types to determine the effect on the growth rate of both species. The second goal was to study the influence of pot leachates from wheat and $L$. multiflorum $\mathrm{x} L$. perenne on the physiological profile of the soil microbial community, determined by using the Biolog EcoPlate ${ }^{\mathrm{TM}}$ system on culturable protozoa, total heterotrophic counts on nutrient agar, and filamentous growth measured in situ.

\section{MATERIALS AND METHODS}

2.1.1 Comparing the effect of pot leachates from wheat and L. multiflorum $x$ L. perenne on the growth of these plant species in two soil types

Topsoil from two diverse localities, namely Langgewens (18 $\left.70^{\circ} \mathrm{E}, 33^{\circ} 27^{\prime} \mathrm{S}\right)$ and Tygerhoek $\left(19^{\circ} 54^{\prime} \mathrm{E}, 34^{\circ} 08^{\prime} \mathrm{S}\right)$ research farms, in the wheat-producing area of the Western Cape, South Africa, was collected prior to commencement of a greenhouse experiment. Herbicide application on the soil collection area was made one year earlier in the form of glyphosate as a pre-plant application, followed by a sulfonyl-urea herbicide applied post-emergence three weeks after crop planting. Soils were therefore collected eleven months after the last herbicide application. Both localities are situated within the Mediterranean climatic zone and have been cultivated with wheat as main crop for more than 100 years. Annual rotational crops include canola, lupine, medic and barley. Soil from Langgewens are residual (pH 6.3) and of Glenrosa (Inceptisol) type (Soil Classification Working Group, 1991), containing $18 \%$ clay and $1.0 \%$ carbon. This soil type consists of a shallow orthic A horizon on lithogenic sediments. Total soil cations at this locality is $10.7 \mathrm{cmol}(+) \mathrm{kg}^{-1}$ and resistance is $600 \mathrm{Ohms}$ (Table 1). The stony loam soil at Tygerhoek are weakly developed residual (pH 5.1) of Mispah (Entisol) type (Soil Classification Working Group, 1991) containing $22 \%$ clay and $1.6 \%$ carbon. This soil type consists of a shallow orthic A horizon on hard rock. Total soil cations at this locality is $8.5 \mathrm{cmol}(+) \mathrm{kg}^{-1}$ and resistance is $370 \mathrm{Ohms}$ (Table 1).

Table 1 Soil analyses of the research farms Langgewens and Tygerhoek, Western Cape, South Africa prior to commencement of the greenhouse study

\begin{tabular}{|l|l|l|l|l|}
\hline Locality & \multicolumn{2}{|c|}{ Langgewens } & \multicolumn{2}{c|}{ Tygerhoek } \\
\hline Soil properties & Value & Unit & Value & Unit \\
\hline $\mathrm{pH}$ & 6.3 & & 5.1 & \\
\hline Resistance & 600 & Ohms & 370 & Ohms \\
\hline Texture & Sandy loam & & Loam & \\
\hline
\end{tabular}


International Journal of Agriculture, Environment and Bioresearch

Vol. 4, No. 06; 2019

ISSN: $2456-8643$

\begin{tabular}{|l|l|l|l|l|}
\hline Acidity & 0.89 & $\mathrm{cmol}(+) / \mathrm{kg}$ & 0.71 & $\mathrm{cmol}(+) / \mathrm{kg}$ \\
\hline Calcium & 3.96 & $\mathrm{cmol}(+) / \mathrm{kg}$ & 3.45 & $\mathrm{cmol}(+) / \mathrm{kg}$ \\
\hline Magnesium & 0.75 & $\mathrm{cmol}(+) / \mathrm{kg}$ & 1.78 & $\mathrm{cmol}(+) / \mathrm{kg}$ \\
\hline Potassium & 220 & $\mathrm{mg} / \mathrm{kg}$ & 305 & $\mathrm{mg} / \mathrm{kg}$ \\
\hline Sodium & 23 & $\mathrm{mg} / \mathrm{kg}$ & 63 & $\mathrm{mg} / \mathrm{kg}$ \\
\hline P (citric acid) & 99 & $\mathrm{mg} / \mathrm{kg}$ & 40 & $\mathrm{mg} / \mathrm{kg}$ \\
\hline Total cations & 10.72 & $\mathrm{cmol}(+) / \mathrm{kg}$ & 8.49 & $\mathrm{cmol}(+) / \mathrm{kg}$ \\
\hline Copper & 1.63 & $\mathrm{mg} / \mathrm{kg}$ & 1.26 & $\mathrm{mg} / \mathrm{kg}$ \\
\hline Zinc & 5.59 & $\mathrm{mg} / \mathrm{kg}$ & 1.58 & $\mathrm{mg} / \mathrm{kg}$ \\
\hline Manganese & 191.3 & $\mathrm{mg} / \mathrm{kg}$ & 120.20 & $\mathrm{mg} / \mathrm{kg}$ \\
\hline Sulphur & 3.61 & $\mathrm{mg} / \mathrm{kg}$ & 9.84 & $\mathrm{mg} / \mathrm{kg}$ \\
\hline Boron & 0.32 & $\mathrm{mg} / \mathrm{kg}$ & 1.49 & $\mathrm{mg} / \mathrm{kg}$ \\
\hline Carbon & 0.98 & $\%$ & 1.55 & $\%$ \\
\hline
\end{tabular}

The experimental lay-out was based on research methods followed by Reinhardt et al. (1994), Hoffman et al. (1996) and Smith et al. (2001) for assessing whether crop root exudates release phytotoxins that affect the growth and yield of crops and weeds. In this study wheat (Triticum aestivum cv. SST 027) and L. multiflorum x L. perenne were used as "donor" plant series from which pot leachates were collected twice weekly to treat the "acceptor" plant series of wheat and L. multiflorum x L. perenne grown in separate pots with similar layout and number. Pots (pot diameter $17 \mathrm{~cm}$; depth $20 \mathrm{~cm}$ ) were filled with $6 \mathrm{~kg}$ of topsoil from either Langgewens or Tygerhoek and placed on steel tables designed to accommodate the placement of funnels on top of $1 \ell$ brown glass bottles to collect pot leachates. For both the donor and acceptor plant series, six seeds of each plant species were sown and thinned to three plants of similar size one week after emergence. The plants were grown in the greenhouse at a constant temperature of $18{ }^{\circ} \mathrm{C}$ with natural lighting in the months of May to October (southern hemisphere) from wheat growth stage one (germination) up to stage 19 (booting stage) when all the leaves on the main tiller have appeared and the apex were visible above the flag leaf ligula. At two weeks after sowing, $0.1 \mathrm{~g} \mathrm{~N}$ in the form of limestone ammonium nitrate (LAN) was added to all pots. For the first two weeks after sowing, $100 \mathrm{ml}$ Multifeed (Plaaskem (Pty) Ltd, Witfield, South Africa) was applied weekly as a balanced plant nutrition solution at a concentration of $1 \mathrm{~g}^{-1}$, to each pot. Each donor pot was over-irrigated bi-weekly with de-ionised water from the first week after planting to ensure drainage from pots. In the case of the donor series all water leached from the same plant type, was mixed in a single brown glass container and used as leachate treatment for a particular acceptor plant grown in a separate pot. No sowing was done in control pots, but the leachate was collected in the same way as described above and used for the control treatment. Treatments in 
the greenhouse were replicated three times in a randomised block design and the experiment was repeated once.

Of the leachates collected from the "donor" plant series, $150 \mathrm{ml}$ was transferred biweekly to the acceptor plant series. Water analyses of leachate collected from L. multiflorum $\mathrm{x} L$. perenne grown on Tygerhoek soil indicated $\mathrm{pH}$ as 6.6 , conductivity 8 , total dissolved solids (TDS) $52 \mathrm{mg} \ell^{-1}$ and alkalinity $30 \mathrm{mg} \ell^{-1}$ as $\mathrm{CaCO}_{3}$ per $\mathrm{mg}^{-1}$ (Table 2). In this way the leachates from a particular donor species and non-planted control donor pots was applied to acceptor plants of the same type as well as to each of the other acceptor plant types and the nonplanted control acceptor pots. The first transfer of leachate took place at the time of planting, and thereafter bi-weekly up to ten weeks after emergence at growth stage 19 (booting stage) when all the leaves on the main tiller have appeared and the apex were visible above the flag leaf ligula.

Table 2 Analyses of leachates from potsin which either wheat or ryegrass hybrid type (Lolium multiflorum $\times$ L. perenne) was grown in pots containing soils of the research farms Langgewens and Tygerhoek, Western Cape, South Africa

\begin{tabular}{|l|l|l|l|l|l|}
\hline & \multicolumn{1}{|c|}{$\begin{array}{c}\text { Water } \\
\text { source }\end{array}$} & \multicolumn{4}{|c|}{ Soil source } \\
\hline \multicolumn{1}{|c|}{$\begin{array}{c}\text { Water } \\
\text { properties }\end{array}$} & $\begin{array}{c}\text { Irrigation } \\
\text { water }\end{array}$ & $\begin{array}{c}\text { Wheat } \\
\text { Leachate }\end{array}$ & $\begin{array}{c}\text { L. } \\
\text { multiflorum } \\
x \text { L. perenne }\end{array}$ & $\begin{array}{c}\text { Wheat } \\
\text { Leachate }\end{array}$ & $\begin{array}{c}\text { L. } \\
\text { multiflorum } x \\
\text { L. perenne }\end{array}$ \\
\hline $\mathrm{pH}$ & 8.2 & 7.3 & 7.3 & 6.8 & 6.6 \\
\hline Conductivity & $10 \mathrm{mS} / \mathrm{m}$ & $13 \mathrm{mS} / \mathrm{m}$ & $12 \mathrm{mS} / \mathrm{m}$ & $10 \mathrm{mS} / \mathrm{m}$ & $8 \mathrm{mS} / \mathrm{m}$ \\
\hline TDS & $65 \mathrm{mg} / \ell$ & $85 \mathrm{mg} / \ell$ & $78 \mathrm{mg} / \ell$ & $65 \mathrm{mg} / \ell$ & $52 \mathrm{mg} / \ell$ \\
\hline Calcium & $16 \mathrm{mg} / \ell$ & $16 \mathrm{mg} / \ell$ & $15 \mathrm{mg} / \ell$ & $12 \mathrm{mg} / \ell$ & $11 \mathrm{mg} / \ell$ \\
\hline Magnesium & $1 \mathrm{mg} / \ell$ & $4 \mathrm{mg} / \ell$ & $2 \mathrm{mg} / \ell$ & $3 \mathrm{mg} / \ell$ & $3 \mathrm{mg} / \ell$ \\
\hline Potassium & $1 \mathrm{mg} / \ell$ & $9 \mathrm{mg} / \ell$ & $5 \mathrm{mg} / \ell$ & $16 \mathrm{mg} / \ell$ & $8 \mathrm{mg} / \ell$ \\
\hline Sodium & $5 \mathrm{mg} / \ell$ & $7 \mathrm{mg} / \ell$ & $7 \mathrm{mg} / \ell$ & $6 \mathrm{mg} / \ell$ & $4 \mathrm{mg} / \ell$ \\
\hline Chloride & $17.8 \mathrm{mg} / \ell$ & $14.2 \mathrm{mg} / \ell$ & $14.2 \mathrm{mg} / \ell$ & $10.7 \mathrm{mg} / \ell$ & $7.1 \mathrm{mg} / \ell$ \\
\hline Sulphate & $7 \mathrm{mg} / \ell$ & $10 \mathrm{mg} / \ell$ & $10 \mathrm{mg} / \ell$ & $3 \mathrm{mg} / \ell$ & $2 \mathrm{mg} / \ell$ \\
\hline Bicarbonate & $25 \mathrm{mg} / \ell$ & $35 \mathrm{mg} / \ell$ & $25 \mathrm{mg} / \ell$ & $40 \mathrm{mg} / \ell$ & $30 \mathrm{mg} / \ell$ \\
\hline Cations & $1.13 \mathrm{meq} / \ell$ & $2.25 \mathrm{meq} / \ell$ & $1.69 \mathrm{meq} / \ell$ & $3.22 \mathrm{meq} / \ell$ & $1.87 \mathrm{meq} / \ell$ \\
\hline Anions & $1.06 \mathrm{meq} / \ell$ & $1.33 \mathrm{meq} / \ell$ & $1.18 \mathrm{meq} / \ell$ & $1.16 \mathrm{meq} / \ell$ & $0.88 \mathrm{meq} / \ell$ \\
\hline Copper & $0.02 \mathrm{mg} / \ell$ & $0.03 \mathrm{mg} / \ell$ & $0.04 \mathrm{mg} / \ell$ & $0.02 \mathrm{mg} / \ell$ & $0.02 \mathrm{mg} / \ell$ \\
\hline
\end{tabular}


International Journal of Agriculture, Environment and Bioresearch

Vol. 4, No. 06; 2019

ISSN: $2456-8643$

\begin{tabular}{|l|l|l|l|l|l|}
\hline Iron & $0.07 \mathrm{mg} / \ell$ & $9.60 \mathrm{mg} / \ell$ & $5.90 \mathrm{mg} / \ell$ & $11.10 \mathrm{mg} / \ell$ & $12.35 \mathrm{mg} / \ell$ \\
\hline Alkalinity & $25 \mathrm{mg} / \ell$ & $35 \mathrm{mg} / \ell$ & $25 \mathrm{mg} / \ell$ & $40 \mathrm{mg} / \ell$ & $30 \mathrm{mg} / \ell$ \\
\hline Hardness & $44 \mathrm{mg} / \ell$ & $56 \mathrm{mg} / \ell$ & $46 \mathrm{mg} / \ell$ & $42 \mathrm{mg} / \ell$ & $40 \mathrm{mg} / \ell$ \\
\hline SAR $^{*}$ & 0.33 & 0.41 & 0.45 & 0.40 & 0.28 \\
\hline LSI $^{*}$ & -0.56 & -1.33 & -1.50 & -1.89 & -2.24 \\
\hline Ryznar index & 9.3 & 10.0 & 10.3 & 10.6 & 11.1 \\
\hline $\begin{array}{l}\text { Aggressiveness } \\
\text { index }\end{array}$ & 11.2 & 10.4 & 10.3 & 9.9 & 9.5 \\
\hline
\end{tabular}

*TDS - Total Dissoved Solids; SAR - Sodium adsorption ratio; LSI - Langelier Saturation Index

Plant height of acceptor plants was measured on a weekly basis using a $1 \mathrm{~m}$ measuring stick. Growth rate was calculated as $\mathrm{cm}$ gained per day. Data for each soil type were analysed separately, because of differences in plant growth patterns between the two localities. All data were averaged over the two sets of data for each locality and were analysed statistically (ANOVA) with the statistical program SAS. Least significant difference (LSD) values were used to differentiate between the effects of the donor plant series on the acceptor plant series at the 5\% level of probability.

\subsection{Microbial analyses}

All microbial experiments were conducted on mixed topsoil from Langgewens prior to any treatment (termed "Before") and again at the end of the trial period when the plants were fully grown after 70 days at growth stage 19 (booting stage) when all the leaves on the main tiller have appeared and the apex were visible above the flag leaf ligula. Only soil from Langgewens was used for microbial analyses because the leachate effects from these pots were more pronounced on wheat (Ferreira, 2011).

To determine microbial activity at the end of the trial period, whole community metabolic analyses were performed (Garland \& Mills, 1991). Soil samples of $10 \mathrm{~g}$ each were taken before filling of the pots to serve as reference point. After harvesting the plants, a $10 \mathrm{~g}$ soil sample was taken from each treatment. All samples were stored in new plastic bags at $5{ }^{\circ} \mathrm{C}$ and analysed within a week. Analyses commenced by suspending each sample in $90 \mathrm{ml}$ sterile distilled water. After shaking for 10 minutes the sample was inoculated directly into Biolog EcoPlate ${ }^{\mathrm{TM}}$ (Biolog, Haywood, CA, USA) as a soil suspension and incubated at $22{ }^{\circ} \mathrm{C}$ in the dark. After 48 hours the microbial community-level physiological profile (CLPP) was assessed for colour development. Utilisation of the carbon source in each well, as indicated by a reduction of the tetrazolium dye, was then recorded as either negative (carbon source not used) or positive (carbon source used).

Soil dilution plates were used to enumerate heterotrophic microbes in the soil samples. A $100 \mu \mathrm{l}$ aliquot of each dilution in a soil dilution series $\left(10^{-1}-10^{-5}\right)$ was transferred to a Petri dish 
containing nutrient agar (Atlas, 1993) and spread over the surface with a sterile glass-spreading rod. The plates were incubated in the dark for 7 days at room temperature $\left(25^{\circ} \mathrm{C}\right)$. The colony forming units (CFU) were counted manually and $\log$ converted before statistical analysis.

For the enumeration of protozoa, the method known as most probable number (MPN) was used, as described by Rǿnn et al. (1995). A soil extract was prepared and autoclaved to supply microorganisms with nutrients. Next, a soil dilution series $\left(10^{-1}-10^{-6}\right)$ was incubated with the prepared extract for five days at room temperature in the dark. Each well was examined for a maximum of five minutes under an inverted microscope at $100 \mathrm{x}$ magnifications and the presence or absence of protozoa recorded accordingly. These numbers were converted to estimated soil populations using a formula of Briones \& Reichardt (1999).

An adaptation of the buried slide technique (Parkinson et al., 1971) as described by Marais et al. (2010) was used to measure filamentous growth in the soil. Two clean microscope slides were bound together with masking tape. These were then buried upright in the pots, just under the soil surface. After two weeks in the soil, the slides were removed and wiped clean on the outside. The inside of each slide was then examined under a light microscope at $100 \mathrm{x}$ magnification and filamentous growth recorded in 20 fields on each slide. Thus, the possible count was between 0 and 40 for a pair of slides. Percentage filamentous growth was calculated as a percentage of the possible 40 fields per pair of slides.

\subsubsection{Statistical analyses}

All nominal data (heterotrophic counts, filamentous growth percentages as well as total number of carbon sources utilised) were analysed statistically (ANOVA) with the statistical program SAS (2008). Least significant difference (LSD) values were used to differentiate between the effects of the donor plant series on the acceptor plant series at the $5 \%$ level of probability.

Canonical correspondence analysis (CCA) was designed to elucidate the relationship between biological factors and their ecological environment (Ter Braak \& Verdonschot, 1995), therefore CCA was used to study the relationship between the different carbon sources utilised by the soil microbial community, as found with the Biolog EcoPlate ${ }^{\mathrm{TM}}$ system, and the sizes of the different microbial populations determined during this study.

\section{RESULTS}

\subsection{Comparing the effect of leachates on wheat and $L$. multiflorum $\times$ L. perenne growth in two soil types}

Leachates from the donor plants significantly $(\mathrm{P} \leq 0.05)$ affected the growth rate of wheat and $L$. multiflorum x L. perenne (acceptor plants) as shown in the ANOVA (Table 3). The ANOVA indicates that the growth rate of wheat grown on Langgewens soil showed significant treatment differences $(P=0.0054$; Table 3). Significant treatment differences were also observed for the growth rate of L. multiflorum $\mathrm{x}$ L. perenne grown on either Langgewens ( $\mathrm{P}=0.0035$; Table 3 ) or Tygerhoek soil $(\mathrm{P}=0.0018$; Table 3$)$. 
Table 3 Mean Squares and P-values for the ANOVA on the growth rate of wheat and ryegrass hybrid type (Lolium multiflorum $\times$ L. perenne) grown on Langgewens and Tygerhoek soils

\begin{tabular}{|l|c|c|c|c|c|c|c|c|c|}
\hline \multicolumn{2}{|l|}{ Origin of soils used } & \multicolumn{4}{|c|}{ Langgewens } & \multicolumn{4}{c|}{ Tygerhoek } \\
\hline Plant donor series & \multicolumn{3}{|c|}{ Plant acceptor series } & \multicolumn{3}{c|}{ Plant acceptor series } \\
\hline & \multicolumn{2}{|c|}{ Wheat } & $\begin{array}{c}\text { L. multiflorum } \\
x \text { L. perenne }\end{array}$ & \multicolumn{2}{|c|}{ Wheat } & $\begin{array}{c}\text { L. multiflorum } \\
x \text { L. perenne }\end{array}$ \\
\hline Source & DF & MS & P & MS & P & MS & P & MS & P \\
\hline Rep & 3 & 0.0172 & 0.2558 & 0.0057 & 0.7261 & 0.0475 & 0.0630 & 0.0557 & $<.0001$ \\
\hline Trt & 2 & 0.1384 & 0.0054 & 0.2113 & 0.0035 & 0.0355 & 0.1151 & 0.0210 & 0.0018 \\
\hline Error & 6 & 0.0098 & & 0.0126 & & 0.0112 & & 0.0010 & \\
\hline
\end{tabular}

On Langgewens soil, the growth rate of wheat was significantly more $(\mathrm{P} \leq 0.05)$ inhibited by L. multiflorum $\mathrm{x} L$. perenne leachate than from wheat or control leachate. On Tygerhoek soil no significant effect for wheat growth rate was observed (Table 4).

Contrary to the result for wheat grown on Langgewens soils, the growth rate of $L$. multiflorum $\times$ L perenne was stimulated significantly $(\mathrm{P} \leq 0.05)$ by $L$. multiflorum $\times L$. perenne leachate. On both Langgewens and Tygerhoek soils, the growth rate of L. multiflorum $\mathrm{x} L$. perenne was stimulated significantly $(\mathrm{P} \leq 0.05)$ by its own leachate relative to the control (Table 4).

Table 4 Effect of pot leachates from the "donor" plant series on the growth rate of wheat and ryegrass hybrid type (Loliummultiflorumx $L$. perenne) grownon Langgewens and Tygerhoek soils

\begin{tabular}{|l|l|l|l|l|}
\hline & \multicolumn{4}{|c|}{ Growth rate of acceptor plants $\left(\mathrm{cm} \mathrm{day}^{-1}\right)$} \\
\hline Origin of soils used & \multicolumn{2}{|c|}{ Langgewens } & \multicolumn{2}{c|}{ Tygerhoek } \\
\hline Plant donor series & \multicolumn{2}{|c|}{ Plant acceptor series } & \multicolumn{2}{c|}{ Plant acceptor series } \\
\hline & Wheat & $\begin{array}{l}\text { L. multiflorum } \\
x \text { L. perenne }\end{array}$ & Wheat & $\begin{array}{l}\text { L. multiflorum } \\
x \text { L. perenne }\end{array}$ \\
\hline Wheat & $0.03384 \mathrm{a}$ & $0.03427 \mathrm{~b}$ & $0.02919 \mathrm{a}$ & $0.02992 \mathrm{a}$ \\
\hline $\begin{array}{l}\text { L. multiflorum } x \text { L. } \\
\text { perenne }\end{array}$ & $0.03091 \mathrm{~b}$ & $0.03703 \mathrm{a}$ & $0.02875 \mathrm{a}$ & $0.02941 \mathrm{a}$ \\
\hline Control & $0.03435 \mathrm{a}$ & $0.03247 \mathrm{~b}$ & $0.03056 \mathrm{a}$ & $0.02849 \mathrm{~b}$ \\
\hline LSD $(\mathrm{P}=0.05)$ & 0.0017 & 0.0019 & 0.0018 & 0.0005 \\
\hline Standard error & 0.0005 & 0.0006 & 0.0005 & 0.0001 \\
\hline Coeff variance & 3.0002 & 3.2488 & 3.5912 & 1.0601 \\
\hline
\end{tabular}

*Means within a column followed by the same letter are not significantly different at the 0.05 probability level 


\subsection{Effect of leachates on soil microbial populations}

The leachate from control pots and pots containing L. multiflorum x L. perenne resulted in no significant changes in the microbial communities of the acceptor soil (Table 5). However, leachates from pots containing wheat significantly $(\mathrm{P} \leq 0.05)$ increased the total number of carbon sources utilised by the soil microbial community in the vicinity of wheat and $L$. multiflorum $\mathrm{x} L$. perenne, than for the control. The estimate of protozoa population (log estimated population size) was significantly $(\mathrm{P} \leq 0.05)$ greater using wheat leachate on $L$. multiflorum $\mathrm{x}$ L. perenne acceptor plants than either the control or wheat acceptor plants (Table 5).

Table 5 The effect of leachates collected from "donor" pots, containing either wheat or ryegrass hybrid type (Lolium multiflorum $\times$ L. perenne), on the microbial populations of the soil from Langgewens research farm, Western Cape, South Africa, containing the "acceptor" plants

\begin{tabular}{|c|c|c|c|c|c|}
\hline $\begin{array}{l}\text { Plant } \\
\text { "donor" } \\
\text { series }\end{array}$ & $\begin{array}{l}\text { Treatments - } \\
\text { Plant "acceptor" } \\
\text { series }\end{array}$ & $\begin{array}{l}\text { •Total } \\
\text { carbon } \\
\text { sources } \\
\text { utilised }\end{array}$ & $\begin{array}{l}\text { Heterotrophic } \\
\text { Microbes } \\
\text { (log colony } \\
\text { forming units) }\end{array}$ & $\begin{array}{l}\text { Filamentous } \\
\text { growth (\%) }\end{array}$ & $\begin{array}{l}\text { Protozoa } \\
(\log \\
\text { estimated } \\
\text { population } \\
\text { size) }\end{array}$ \\
\hline \multirow{4}{*}{ Control } & Control & $21.00 \mathrm{a}$ & $7.48 \mathrm{a}$ & $12.5 \mathrm{a}$ & $4.47 \mathrm{a}$ \\
\hline & $\begin{array}{l}\text { L. multiflorum } x \\
\text { L. perenne }\end{array}$ & $15.50 \mathrm{a}$ & $7.47 \mathrm{a}$ & $5.00 \mathrm{a}$ & $5.04 a$ \\
\hline & Wheat & $14.00 \mathrm{a}$ & $7.23 a$ & $8.75 a$ & $4.60 \mathrm{a}$ \\
\hline & $\mathrm{LSD}(\mathrm{P}=0.05)$ & 14.53 & 1.48 & 36.89 & 3.07 \\
\hline \multirow{4}{*}{$\begin{array}{l}\text { L. } \\
\text { multiflorum } \\
\text { x L. perenne }\end{array}$} & Control & $16.67 \mathrm{a}$ & $7.32 \mathrm{a}$ & $8.83 a$ & $4.24 a$ \\
\hline & $\begin{array}{l}\text { L. multiflorum } x \\
\text { L. perenne }\end{array}$ & $18.00 \mathrm{a}$ & $7.40 \mathrm{a}$ & $6.67 a$ & $4.65 a$ \\
\hline & Wheat & $24.33 \mathrm{a}$ & $7.36 \mathrm{a}$ & $2.50 \mathrm{a}$ & $4.41 \mathrm{a}$ \\
\hline & $\mathrm{LSD}(\mathrm{P}=0.05)$ & 8.05 & 0.58 & 11.09 & 0.80 \\
\hline \multirow{3}{*}{ Wheat } & Control & $16.67 b$ & $7.35 \mathrm{a}$ & $2.5 \mathrm{a}$ & $4.27 b$ \\
\hline & $\begin{array}{l}\text { L. multiflorum } x \\
\text { L. perenne }\end{array}$ & $20.00 \mathrm{a}$ & $7.54 \mathrm{a}$ & $19.17 \mathrm{a}$ & $5.00 \mathrm{a}$ \\
\hline & Wheat & $22.67 \mathrm{a}$ & $7.52 \mathrm{a}$ & $10.83 a$ & $4.33 b$ \\
\hline
\end{tabular}


Vol. 4, No. 06; 2019

ISSN: $2456-8643$

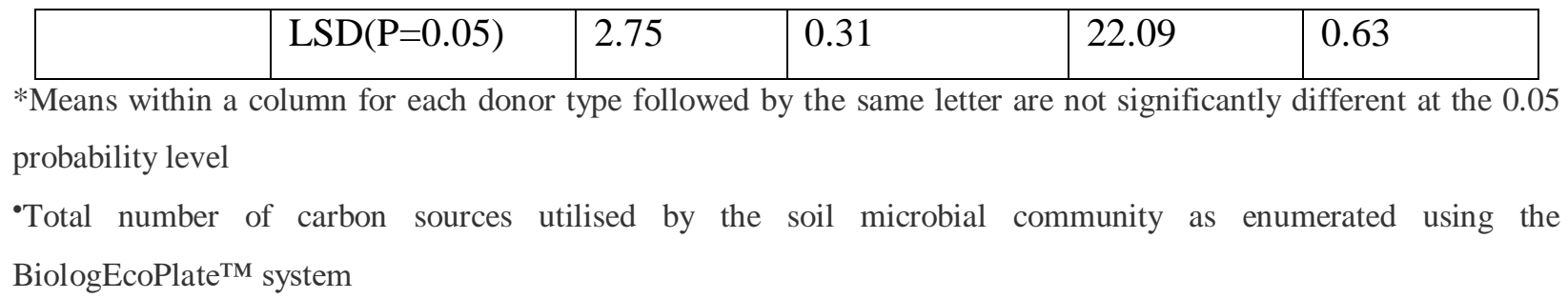

Canonical correspondence analysis was employed to study the relationship between the different carbon sources utilised by the soil bacterial community, as found with the Biolog EcoPlate $^{\mathrm{TM}}$ system, the measured microbial populations (filamentous growth, heterotrophic microbes, protozoa) and the different treatments (Figure 1, Table 5). The leachates originating from the different treatments resulted in the differences in the response of the soil microbial community. The reference point for this study is indicated in the bottom right quadrant by "Before-Before", which depicts non-planted (control) pots receiving leachate from control pots containing non-planted (control) soil (Figure 1). From the top right quadrant in Figure 1, it can be deduced that microbes with similar profiles in the rhizosphere of wheat receiving leachates from both wheat or L. multiflorum $\mathrm{x}$ L. perenne was associated with increased utilisation of the majority of carbon sources, namely C6, C12, C22, C24, C28, C29 and C30 (Table 6), increased heterotrophic counts, as well as filamentous growth. Also, the soil microbial community of nonplanted (control) soil which received soil leachate from non-planted pots clustered together and was associated with increased utilisation of the same carbon sources mentioned above, increased heterotrophic counts, as well as filamentous growth.

The top left quadrant of Figure 1 showed that higher protozoan numbers were observed in the rhizosphere of $L$. multiflorum x $L$. perenne which received leachates from either wheat or $L$. multiflorum x $L$. perenne as it clustered together. Also, the rhizosphere of wheat receiving control leachate was correlated to protozoan numbers. A microbial community able to readily utilise $\alpha$ ketobutyric acid (Figure $1 \&$ Table 6; C27) was observed when L. multiflorum x $L$. perenne leachate was added to non-planted control pots. The bottom left quadrant showed that non-planted control pots receiving wheat leachate, cannot be positively associated with carbon utilisation. The bottom right quadrant indicated that L. multiflorum $\mathrm{x}$ L. perenne which received control leachate was associated with the ability of the soil microbial community to utilise carbon sources 19 and 20 (Figure $1 \&$ Table 6).

The top right quadrant in Figure 1 showed that a negative correlation existed between the soil microbial community of wheat which received soil leachate from wheat and the microbial profile indicated in the bottom left quadrant for control pots receiving wheat leachate. The top left quadrant indicated a negative correlation between the microbial profile in control pots receiving leachate from $L$. multiflorum $\mathrm{x} L$. perenne and the microbial community in the bottom right quadrant of $L$. multiflorum $\times$ L. perenne which received control leachate.

Figure legend 


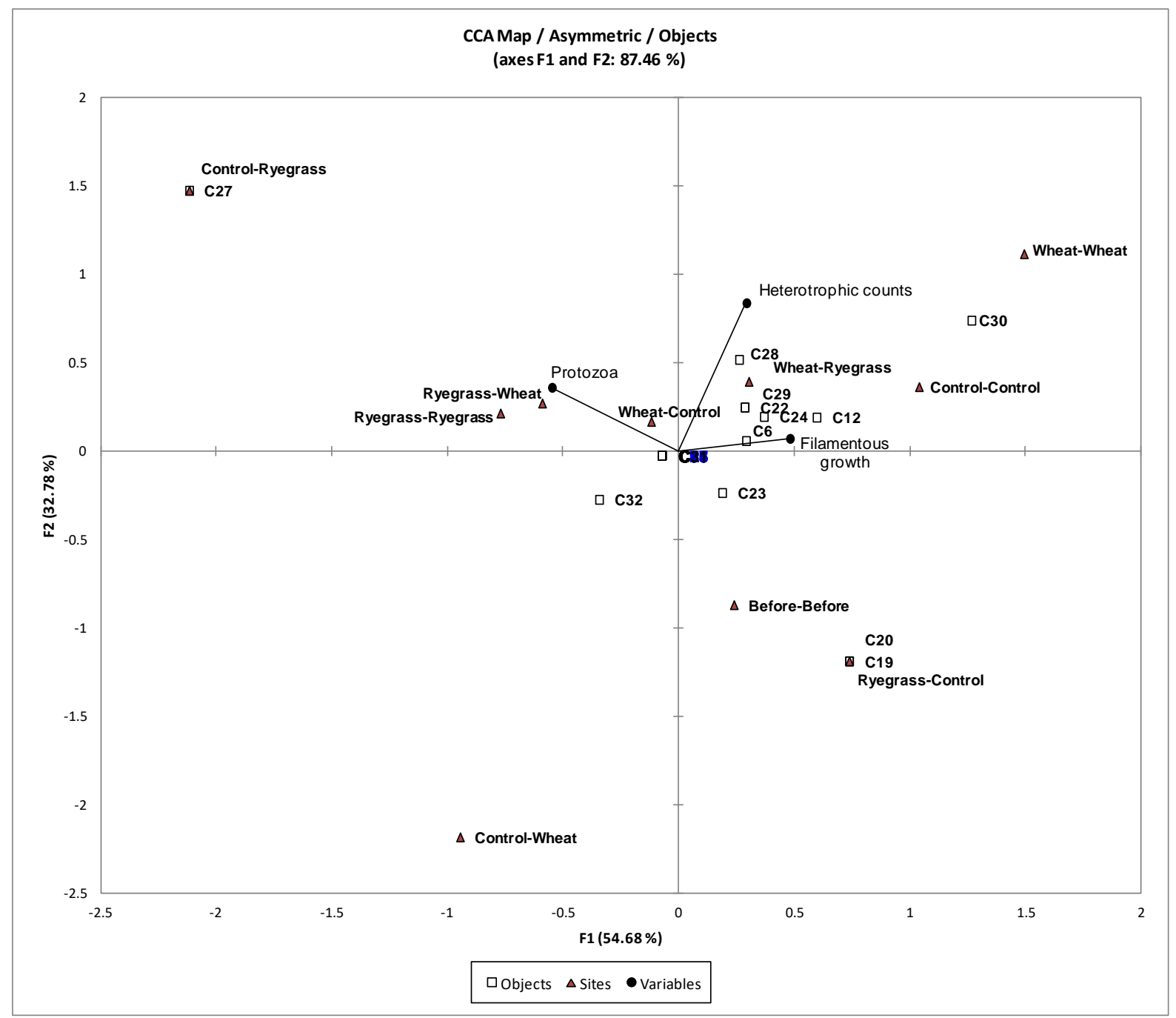

Figure 1 Canonical correspondence analysis (CCA) indicating the relationship between mutual treatments of wheat and ryegrass hybrid type (Lolium multiflorum $\mathrm{x}$ L. perenne) leachates on the frequency of the different carbon sources (as listed in Table 4) utilised by the soil microbes, the heterotrophic counts, filamentous growth and numbers of protozoa. Treatments are expressed by "acceptor" and then "donor" plant treatments.

Table $6 \mathrm{~A}$ list of the different carbon sources recorded in the BiologEcoPlate ${ }^{\mathrm{TM}}$ system and utilised by microbes in soils from Langgewens in the Western Cape, South Africa, on which wheat or ryegrass hybrid type (Lolium multiflorum $\times$ L. perenne) was grown

\begin{tabular}{|c|c|}
\hline Carbon source & Carbon source \\
\hline
\end{tabular}


Vol. 4, No. 06; 2019

ISSN: $2456-8643$

\begin{tabular}{|c|l|l|l|}
\hline 1 & Water (non-carbon control) & C17 & $\alpha$-Cyclodextrin \\
\hline C2 & ß-Methyl-D-Glucoside & C18 & N-Acetyl-D-Glucosamine \\
\hline C3 & D-Galactonic Acid $\gamma$-Lactone & C19 & $\gamma$-Hydroxibutyric Acid \\
\hline C4 & L-Arginine & C20 & L-Threonine \\
\hline C5 & Pyruvic Acid Methyl Ester & C21 & Glycogen \\
\hline C6 & D-Xylose & C22 & D-Glucosaminic Acid \\
\hline C7 & D-Galacturonic Acid & C23 & Itaconic Acid \\
\hline C8 & L-Asparagine & C24 & Glycyl-L-Glutamic Acid \\
\hline C9 & Tween 40 & C25 & D-Cellobiose \\
\hline C10 & I-Erythritol & C26 & Glucose-1-Phosphate \\
\hline C11 & 2-Hydroxy-Benzoic Acid & C27 & $\alpha$ Ketobutyric Acid \\
\hline C12 & L-Phenylalanine & C28 & Phenylehthylamine \\
\hline C13 & Tween 80 & C29 & $\alpha$-D-Lactose \\
\hline C14 & D-Mannitol & C30 & D,L- $\alpha$-Glycerol Phosphate \\
\hline C15 & 4-Hydroxy Benzoic Acid & C31 & D-Mallic Acid \\
\hline C16 & L-Serine & C32 & Putrescine \\
\hline
\end{tabular}

\section{DISCUSSION}

The leachates from the different plant species changed the measurable microbial community in the same acceptor pots. All the pots should have had the same general microbial community before the treatments commenced, since the washed pots all received the same mixed topsoil and only de-ionised water was used for pot irrigation. It can be assumed that the differences were jointly caused by the effect of watering (as in control leachate used to treat control acceptor pots) and the root exudates from the donor pots. However, it should be borne in mind that each pot, except the controls, was subjected to the effects of root exudates from the planted crop or weed.

Bertin et al. (2003) reported that root exudation serves as an important carbon and energy source for microbes contained in the rhizosphere. Results from previous experiments indicated that soil microbial populations are affected by compounds released by the different plant species which were contained in the leachates (Ferreira, 2011). Therefore, it is conceivable that some soil microbial populations were enriched by utilisation of particular carbon sources, thereby influencing the growth rate of wheat grown on either Langgewens or Tygerhoek soils. Generally, the investigated plant species showed not only different plant-microbe associations, thus confirming results by Oberan et al. (2008) and Kong et al. (2008), but the results also pointed to the presence of different chemical compounds for each plant species. Kong et al. (2008) also reported that the compounds released from allelopathic cultivars affected populations of soil microbes. The non-significance observed for wheat growth rate on Tygerhoek soil, most probably indicates that either no growth-promoting or growth-inhibiting substances occurred in leachates, emphasising the importance of differences in soil type responses. It is also possible that in this particular soil the allelochemicals contained in the leachates were so rapidly inactivated by microbial action that plant growth was not affected. In addition to the chemical and physical variation between the two soil types used, a different leachate composition yielded 
by each plant species, and possibly differential inactivation of allelochemicals by microbes may be implicated. An association with microbes utilising particular carbon sources when treated with leachate from wheat, was indicated by principal component analysis (PCA) in a previous study (Ferreira, 2011). In this study the significantly slower growth rate of wheat can most probably be attributed to L. multiflorum $\mathrm{x}$ L. perenne leachate which contained substances that inhibited wheat growth rate. In contrast, the significantly higher growth rate of L. multiflorum $\mathrm{x}$ L. perenne may be attributed to its leachate containing substances that show no autotoxicity and increased $L$. multiflorum x $L$. perenne growth rate. These results correspond with findings of interspecies stimulation by McCauley (2009).

The phenomenon of a shift towards a microbial community able to readily utilise $\alpha$ ketobutyric acid as revealed by canonical correspondence analysis (CCA) may have resulted from increased concentrations of this or similar compounds, originating from the L. multiflorum x $L$. perenne root exudates (Kools et al., 2009) in the leachate, ultimately selecting for bacterial populations able to rapidly utilise $\alpha$ keto-butyric acid. Furthermore, the close correlation of protozoan numbers with the utilisation of $\alpha$ keto-butyric acid, suggest that the protozoa actively grazed on this altered microbial community. It is known that protozoa are capable of selecting their food according to size or chemical composition (Rǿnn et al., 2002). Since the Biolog EcoPlate ${ }^{\mathrm{TM}}$ system used in this study mainly estimates the metabolic potential of the rapidly growing bacterial community of the soil it is conceivable that protozoan numbers were also significantly influenced by wheat leachate, because protozoa are known to actively graze on several bacterial species (Clarholm, 1981). Furthermore, the negative correlation shown by the opposing treatments and displayed between the microbial profile in control pots receiving leachate from $L$. multiflorum $\mathrm{x} L$. perenne and the microbial community of $L$. multiflorum $\mathrm{x} L$. perenne which received control leachate provided strong confirmation of the validity of results. It is also an indication that L. multiflorum $\mathrm{x} L$. perenne may change the microbial profile to benefit itself, through the release of root exudates. Indeed, in recent experiments by Teste et al. (2017) it was shown that effects on plant performance by soil microbiota through plant-soil feedbacks, were dependent on the plant nutrient strategy and soil nutrient conditions. Canarini et al. (2018) concluded that these results are extremely important and highlight our need to understand how plant nutrient strategies affect root exudation patterns and how this can elicit feedback on plant community assembly.

Gu et al. (2008a) and Kong et al. (2008) suggested that allelopathic crops and weeds could modify the microbial community structure in soil to their advantage through the release of allelochemicals. Kong (2008) confirmed that variation of the soil microbial populations and community structures could be distinguished by the allelopathic and non-allelopathic crop varieties tested. Although the present study did not only consider the effects of allelochemicals contained in leachates, but the combined effects of all solutes contained in them, it was indicated that the effect on soil microbial population and community structure may be pronounced. This corresponds with the findings of Kong (2008) that the composition of soil microbes is defined at least in part by the nature and amount of chemicals contained in root exudates. Therefore, we contend that the growth rate of test plants in this study could be ascribed to the combination of compounds contributed by root exudates and soil microbial populations. 
Kato-Noguchi et al. (2009) speculated that the secretion of allelopathic compounds into the rhizosphere might provide a competitive advantage for root establishment through local suppression of pathogenic soil microbes and inhibition of the growth of competing plant species. El-Shatnawi \& Makhadmeh (2001) suggested that rhizosphere micro-organisms have positive or negative effects on plant growth and morphology by affecting the plant hormone balance, plant enzymatic activity, nutrient availability and toxicity, and competition with other plants. Plants can modify the rhizosphere in other ways than through the release of allelochemicals, e.g. by causing changes in soil $\mathrm{pH}$, nutrient and moisture levels and as a result can modify the local plant community. However, beneficial and deleterious rhizosphere bacteria play an important role in manipulating root and plant growth (Rolfe et al., 1997). Canarini et al. (2018) confirmed that soil microbes actively consume root exudates and keep concentrations of the respective substance low in the soil environment and at the same time can stimulate specific root exudation patterns. Nevertheless, Xue et al. (2018) concluded that basic questions about how microbial communities are structured and assembled in agroecosystems remain, but that manipulating microbial communities to promote sustainability of crop production, will only be possible if the communities are not wholly determined by fixed factors, such as soil types. In this study, leachates from donor plants had a definite influence on the functional soil microbial community of acceptor plants. These conclusions correspond with those reviewed by Bertin et al. (2003) that roots release leachates containing allelochemicals at significant rates to soil microbes and that these organisms are an important determinant of allelopathic activity (Inderjit, 2005).

\section{CONCLUSION}

It can be concluded that the growth rate of test plants in this study could be ascribed to the combination of compounds contributed by root exudates and soil microbial populations. Therefore, leachate from donor plants had a definite influence on the functional soil microbial community of acceptor plants, which may be due to the fact that leachate released from plant seedlings grown on Langgewens soil, contained substances which increased plant growth rate. This suggests that production practices most probably alters microbial populations and that these influences take place within the context of a specific soil type. Furthermore, the close correlation of protozoan numbers with the utilisation of $\alpha$ keto-butyric acid, originating from the $L$. multiflorum $\mathrm{x}$ L. perenne root exudates, suggest that the protozoa actively grazed on this altered microbial community.

\section{ACKNOWLEDGEMENTS}

Funding by both Grain South Africa and the Western Cape Department of Agriculture is greatly appreciated. The authors have no conflict of interest to declare.

\section{REFERENCES}

ATLAS RM (1993) Alphabetical listing of Media IN: Handbook of Microbiological Media, L. C. Parks, editor, p. 666. CRC Press, London. 
BERTIN C, YANG X \& WESTON LA (2003) The role of root exudates and allelochemicals in the rhizosphere. Plant and Soil 256, 67-83.

BRIONES AM, Jr \& REICHARDT W (1999) Estimating microbial population counts by 'most probable number' using Microsoft Excel®. Journal of Microbiological Methods 35, 157161.

CANARINI A, KAISER C, MERCHANT A, RICHTER A \& WANEK W (2018) Root exudation of primary metabolites: mechanisms and their roles in plant responses to environmental stimuli. Frontiers in Plant Science 10:157. doi:10.3389/fpls.2019.00157

CLARHOLM M (1981) Protozoan grazing of bacteria in soil - impact and importance. Microbial Ecology 7(4), 343-530.

EISENHAUSER N, LANOUE A, STRECKER T, SCHEU S, STEINAUER K, THAKUR MP \& MOMMER L (2017) Root biomass and exudates link plant diversity with soil bacterial and fungal biomass. Scientific Reports 7:44641. Doi: 10.1038/srep44641

ELLIS RJ, MORGAN P, WIGHTMANN AJ \& FRY JC (2003) Cultivation-dependent and independent approaches for determining bacterial diversity in heavy-metal-contaminated soil. Applied Environmental Microbiology 69, 3223 - 3230.

EL-SHATNAWI MKJ \& MAKHADMEH IM (2001) Ecophysiology of the plant-rhizosphere system. Journal of Agronomy and Crop Science 187, 1-9.

FERREIRA MI (2011) Allelopathic interactions between wheat, selected crop species and the weed Lolium multiflorum x perenne. PhD thesis. University of Pretoria. Pretoria, South Africa.

FERREIRA Ml, REINHARDT CF, LAMPRECT SC, SINCLAIR M, MacKENZIE L \& Van COLLER G (2015) Morphological identification of the ryegrass hybrid Lolium multiflorum $\mathrm{x}$ Lolium perenne and isolation of the pathogen Fusarium pseudograminearum in the Western Cape. South African Journal of Plant and Soil. 32(1), 9-15.

GARLAND JL \& MILLS AL (1991) Classification and characterization of heterotrophic microbial communities on the basis of patterns of community level sole-carbon-source utilization. Applied and Environmental Microbiology 57, 2351-2359.

GARLAND JL, CAMPBELL CD \& MILLS AL (2007) Physiological Profiling of Microbial Communities IN: Manual of Environmental Microbiology $3^{\text {rd }}$ Edition. ASM Press, Washington DC. USA; 126-138.

GRAYSTON SJ, WANG S, CAMPBELL CD \& EDWARDS AC (1998) Selective influence of plant species on microbial diversity in the rhizosphere. Soil Biological Biochemistry 30(3), 369-378.

GU Y, LI HB \& KONG CH (2008a) Allelopathic potential of barnyard grass on rice and soil microbes in paddy. Allelopathy Journal 21, 389-396.

GU Y, WANG P \& KONG CH (2008b) Effects of rice allelochemicals on the microbial community of flooded paddy soil. Allelopathy Journal 21, 299-310.

HOFFMANN ML, WESTON LA, SNYDER JC \& REGNIER EE (1996) Allelopathic influence of germinating seeds and seedlings of cover crops on weed species. Weed Science 44, $579-584$.

INDERJIT (2005) Soil microorganisms: an important determinant of allelopathic activity. Plant and Soil 274, 227-236. 
JUHANSON J, TRUU J, HEINARU E \& HEINARU A (2007) Temporal dynamics of microbial community in soil during phytoremediation field experiment. Journal of Environmental Engineering and Landscape Management 15(4), 213-220.

KATO-NOGUCHI H, SALAM MA \& KOBAYASHI T (2009) A quick seeding test for allelopathic potential of Bangladesh rice cultivars. Plant Production Science 12, 47-49.

KAZINCZI G, HORVÁTH J \& TAKÁCS AP (2005) Plant-plant and plant-virus interactions. Lectures and papers presented at the 7th Slovenian Conference on Plant Protection, Zreče, Slovenia, 8-10 March pp. 490-494.

KONG CH (2008) Rice allelopathy. Allelopathy Journal 21, 261-274.

KOOLS SAE, BOIVIN MEY, Van Der WURFF AWG, BERG MP, Van GESTEL CAM \& Van STRAALEN NM (2009) Assessment of structure and function in metal polluted grasslands using Terrestrial Model Ecosystems. Ecotoxicology and Environmental Safety 72, 51-59.

MARAIS A, HARDY MB, MORRIS CD \& BOTHA A (2010) Measuring culturable microbial populations and filamentous microbial growth in soil of wheat plots subjected to crop rotation and monoculture. South African Journal of Plant and Soil, 27(2), 133-141.

McCAULEY RK (2009) Overseeded bermudagrass spring transition response to mowing height, nitrogen rate, sulfonylurea herbicide, and allelopathy. M Sc Thesis. Clemson University. USA. 89pp.

MEHARG AA \& KILLHAM K (1991) A novel method of quantifying root exudation in the presence of soil microflora. Plant and Soil 133, 111-116.

PARKINSON D, GRAY TRG \& WILLIAMS ST (1971) Eds. Methods for studying the ecology of soil micro-organisms. Blackwell Scientific Publications, Oxford, pp. $30-31$.

PENNANEN T (2001) Microbial communities in boreal coniferous forest humus exposed to heavy metals and changes in soil $\mathrm{pH}$ - a summary of the use of phospholipid fatty acids, Biolog ${ }^{\circledR}$ and ${ }^{3} \mathrm{H}$ - thymidine incorporation methods in field studies. Geoderma 100, 91126.

QUIAN JH, DORAN JW \& WALTERS DT (1997) Maize plant contributions to root zone available carbon and microbial transformations of nitrogen. Soil Biology \& Biochemistry 29,1451-1462.

RAHMAN MH, OKUBO A, SUGIYAMA S \& MAYLAND HF (2008) Physical, chemical and microbiological properties of an Andisol as related to land use and tillage practice. Soil Tillage Research 101, 10-19.

REINHARDT CF, MEISSNER R \& LABUSCHAGNE N (1994) Allelopathic interaction of Chenopodium album L. and certain crop species. South African Journal of Plant and Soil 11, 45-49.

ROLFE BG, DJORDJEVIC MA, WEINMANN JJ, MATHESIUS U, PITTOCK C, GARTNER E et al. (1997) Root morphogenesis in legumes and cereals and the effects of bacterial inoculation on root development. Plant and Soil 194, 131-144.

RǿNN R, EKCLUND F \& CHRISTENSEN S (1995) Optimizing soil extract and broth media for MPM-enumeration of naked amoeba and heterotrophic flagellates in soil. Pedobiologia 10, 10-19. 
RǿNN R, McCAIG AE, GRIFFITHS BS \& PROSSER JI (2002) Impact of protozoan grazing on bacterial community structure in soil microcosms. Applied Environmental Microbiology 68(12), 6094-6105.

SAS Institute Inc. (2008) SAS Version 9.2, SAS Institute Inc, SAS Campus Drive, Cary, North Carolina 27513.

SASSE J, MARTINOIA E \& NORTHEN T (2018) Feed your friends: Do plant exudates shape the root microbiome? Trends in Plant Science 23(1), 25-41.

SMITH MW, WOLF ME, CHEARY BS \& CARROLL BL (2001) Allelopathy of bermudagrass, tall fescue, redroot pigweed, and cutleaf evening primrose on pecan. HortScience 36, 1047-1048.

Soil Classification Working Group (1991) Soil classification - a taxonomic system for South Africa. Soil and Irrigation Research Institute, Department of Agricultural Development, Pretoria, South Africa.

Ter BRAAK CJF \& VERDONSCHOT PFM (1995) Canonical correspondence analysis and related multivariate methods in aquatic ecology. Aquatic Sciences 57(3), 255-289.

TESTE FP, KARDOL P, TURNER BL, WARDLE DA, ZEMUNIK G, RENTON M \& LALIBERTÉ E (2017). Plant-soil feedback and the maintenance of diversity in Mediterranean-climate shrublands. Science 355, 173-176.

WESTON LA (2005) History and Current Trends in the Use of Allelopathy for Weed Management. Proceedings of the $4^{\text {th }}$ World Congress on Allelopathy, Wagga Wagga, Australia. 15-21.

XUE D, CHRISTENSON R, GENGER R, GEVENS A \& LANKAU RA (2018) Soil microbial communities reflect both inherent soil properties and management practices in Wisconsin potato fields. American Journal of Potato Research 95, 696-708.

ZHANG CB, WANG J, QIAN BY \& LI WH (2009) Effects of the invader Solidago canadensis on soil properties. Applied Soil Ecology 43, 163-169. 